\title{
Lysozyme and mucins in gastric adenomas
}

\author{
R A CARUSO, F La SPADA, * G CASABLANCA, * L RIGOLI \\ From the Departments of Human Pathology and *Surgery, University of Messina, Italy
}

SUMMARY A method for the simultaneous demonstration of lysozyme and mucins in 39 cases of gastric adenomas differentiated two intermediate cell types. The first was similar to a columnar cell comprising a single cell population which covered extensive areas of the adenomas. This cell type often showed supranuclear lysozyme reactivity and apical neutral mucins, sialomucins, and sulphomucins in variable amounts. The second cell type was found in 11 adenomas, located mainly in the fundal area. It seemed to be a transitional form between the goblet cell and the Paneth cell. This cell type was scattered among columnar cells, occasional Paneth-like cells, and small goblet cells. These two types of intermediate cells may be regarded as abnormally differentiated integral elements of gastric adenomas. They may be associated with the neck stem cells in the cytogenesis of gastric adenomas.

Lysozyme is a bacteriolytic enzyme present in human milk, tears, saliva and serum. It has been detected by immunohistochemical techniques in a variety of human cells and tissue. ${ }^{1-4}$

In the gastrointestinal tract lysozyme is found in the normal epithelial cells of the oesophageal submucosal glands, fundal and pyloric glands, Brunner's glands and Paneth cells. Mucin-producing cells containing lysozyme have been also described in the small intestine of normal rats and patients with inflammatory bowel disease. ${ }^{56}$ Furthermore, mucinsecreting tumour cells containing lysozyme have been observed in gastric carcinoma. ${ }^{78}$

The purpose of this study was to investigate whether intermediate cells were present in gastric adenomas which produce lysozyme and mucins at the same time.

\section{Material and methods}

The ages of the 39 patients ranged from 50 to 91 years (median 75 years). The sex distribution was unequal, with 26 men and 13 women. Thirty nine gastric adenomas were examined histopathologically from material obtained at operation in 20 cases and by endoscopic polypectomy in 19 cases. All specimens were fixed in 10-20\% formalin and embedded in paraffin wax.

Serial sections were stained with haematoxylin and eosin, periodic acid Schiff (PAS), alcian blue, pH 2.5, and high iron diamine.

Accepted for publication 16 March 1989
For the detection of lysozyme, the peroxidaseantiperoxidase (PAP) technique ${ }^{9}$ was used with antibodies obtained from Dakopatts (Copenhagen, Denmark). Serial sections $5 \mu \mathrm{m}$ thick were treated serially for 30 minutes with: (i) $0.1 \%$ hydrogen peroxide in methanol; (ii) non-immune swine serum; (iii) rabbit anti-human lysozyme serum (dilution 1/200); (iv) swine anti-rabbit globulin antiserum (dilution 1/50); (v) rabbit anti-horseradish PAP complexes (dilution 1/100). Peroxidase activity was shown with the 3-3'-diaminobenzidine tetrahydrochloride (Sigma) reaction described by Graham and Karnowsky. ${ }^{10}$

To evaluate the specificity of the lysozyme staining the primary antiserum was replaced by phosphate buffered saline, normal rabbit serum, or absorbed at $4^{\circ} \mathrm{C}$ for 24 hours with purified $90 \%$ protein-lysozyme $(10 \mathrm{nmol})$ extracted from chicken egg white (Sigma Chemical Co).

The simultaneous presence of lysozyme and mucosubstances in the same tissue section was shown by applying the PAP method for the demonstration of lysozyme followed by either PAS or alcian blue. The high iron diamine (HID) method was also applied to serial sections to characterise the sulphomucin positive cells containing lysozyme.

Intestinal metaplasia was divided into types I, IIa, and IIb. "Histological definition of papillary, tubular, and papillotubular adenoma was made according to the WHO classification. ${ }^{12}$ Grading of dysplasia was limited to mild and severe grades as it was based on purely subjective criteria.

Adenomas with a focus of adenocarcinoma were excluded from the present study. 


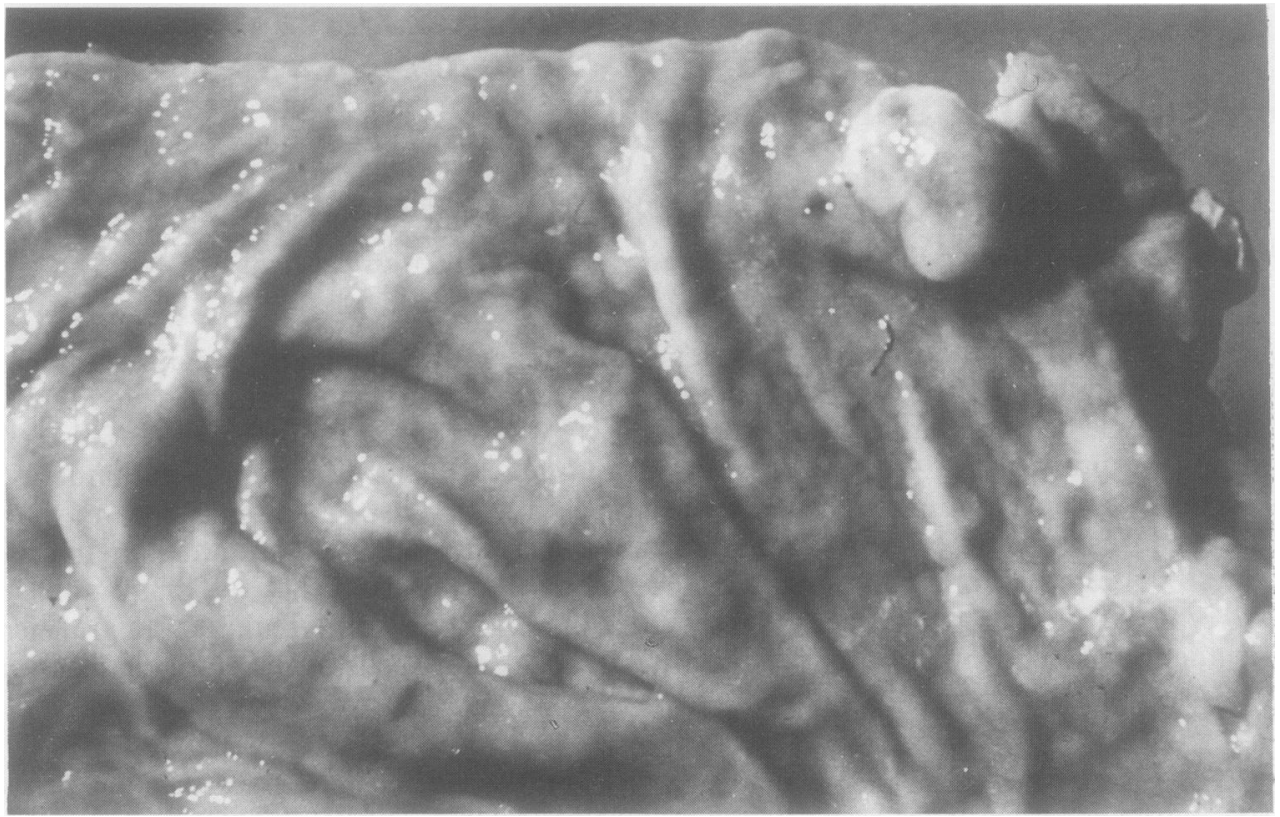

Fig 1 Adenoma in form of circumscribed, hemispheric protrusion in the antrum. Surface of the protrusion is regular.

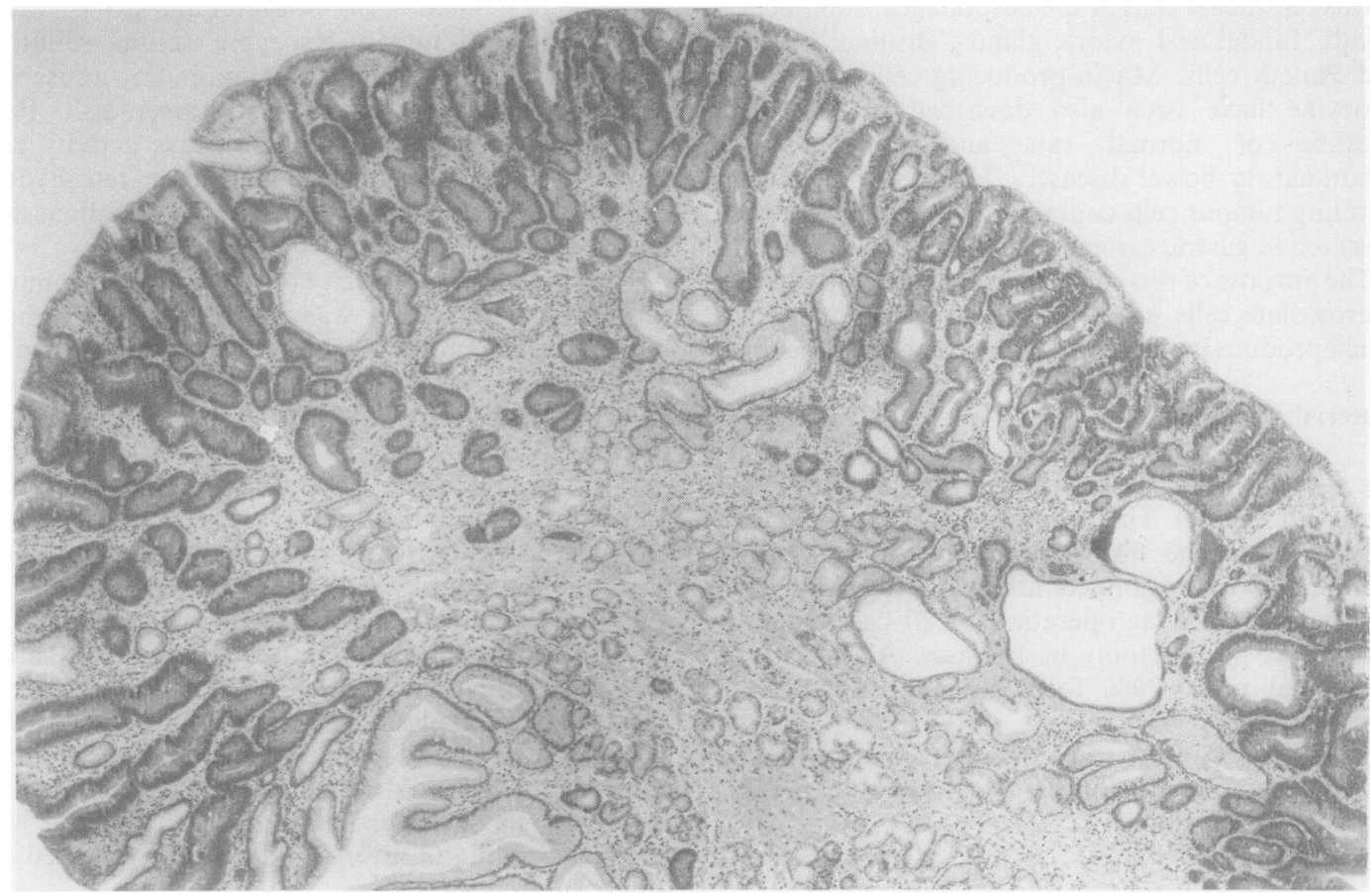

Fig 2 Tubular adenoma of the stomach. Several microcysts are seen in the basal zone; the upper zone is composed of dysplastic foveolar tubules. (Haematoxylin and eosin.) 


\section{Results}

The male: female ratio was $2: 1$. Cases were concentrated in the older age groups, peaking in the seventh decade. Primary location was as follows: $20(51 \%)$ cases in the antral region; $17(43 \%)$ cases in the fundal region; two $(5 \%)$ cases in the cardiac region. Thirty cases were solitary adenomas. In three, adenomas were associated with gastric ulcers; in six cases early gastric cancer was also evident at the same time.

The adenomas were polypoid lesions in $15(38.5 \%)$ cases (fig 1) and flat or slightly raised in $24(61.5 \%)$ cases. The size of the lesions ranged from 0.3 to $2 \mathrm{~cm}$.

Twenty four $(61.5 \%)$ cases were tubular adenomas and 15 cases $(38.5 \%)$ papillotubular adenomas. They were usually composed of two different glandular structures (fig 2). The lower layer contained pylorictype glands of normal appearance or intestinal-type tubules; both types showing cystic dilatation to a variable degree (fig 2). The upper layer comprised dysplastic foveolar tubules. Mild dysplasia was found in $16(41 \%)$ adenomas and severe dysplasia in 23 $(59 \%)$ adenomas.

Mildly dysplastic foveolar tubules were lined by goblet cells and tall columnar cells. Goblet cells secreted sialomucins or sulphomucins, or both. Columnar cells contained neutral mucins, sialomucins, and sulphomucins in varying proportions; their mucin positivity was located on the luminal surface or in the apical portion of the cytoplasm.

Severely dysplastic foveolar tubules were lined by a monomorphic population of columnar cells showing elongated or rounded nuclei with prominent nucleoli. Occasional, small goblet cells were irregularly distributed and secreted a mixture of sialomucins and sulphomucins. In 11 out of 39 adenomas, all of which showed severe dysplasia, there were Paneth-like cells showing cytoplasmic eosinophilic granules, which were stained purple with the alcian blue-PAS stains. Other cells of a similar appearance had PAS positive granular elements in the supranuclear cytoplasm and aggregates of alcian blue positive material in the apical cytoplasm.

\section{LYSOZYME IMMUNOREACTIVITY IN ADENOMAS}

In mildly dysplastic foveolar tubules lysozyme immunoreactivity was weak and limited to some columnar cells. In severely dysplastic foveolar tubules columnar cells showed a moderate to strong lysozyme staining in the supranuclear cytoplasm (fig 3). Panethlike cells were scattered among columnar cells in severely dysplastic areas in 11 adenomas, located in the fundal region $(n=10)$ and in the antral region $(n=1)$. These Paneth-like cells showed a lysozyme positivity in granular elements within the apical and supranuclear cytoplasm.

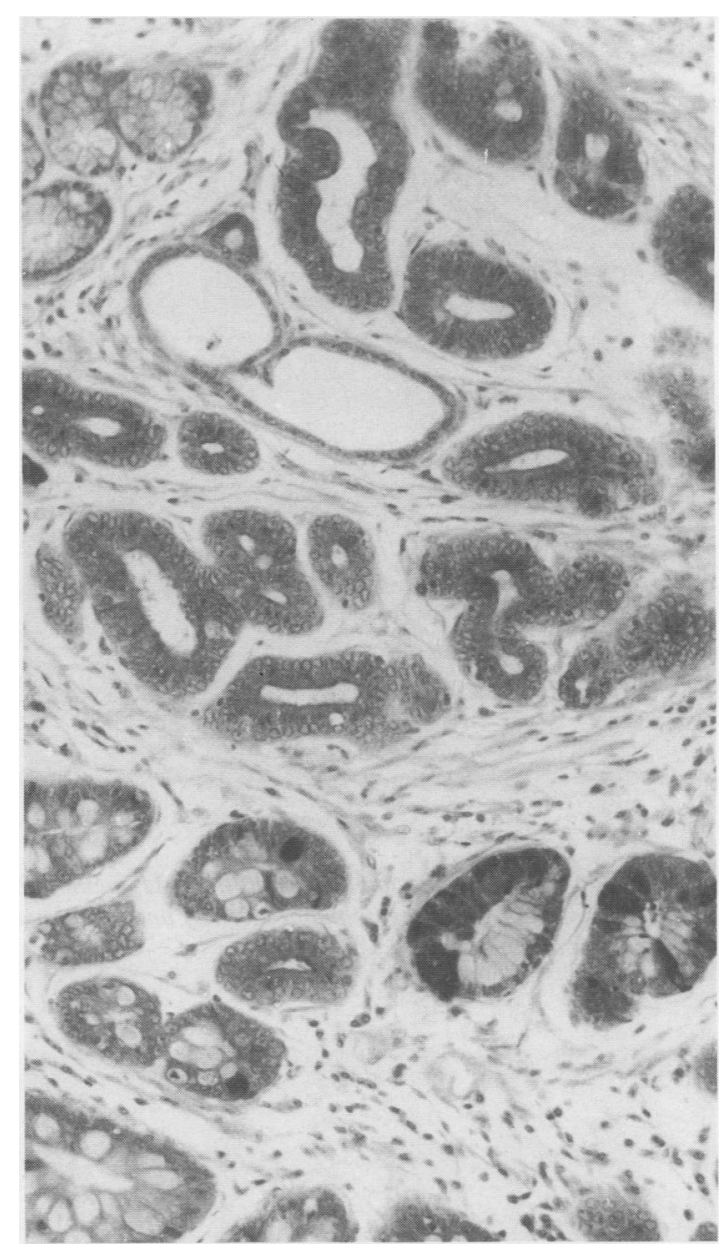

Fig 3 Strong lysozyme reactivity in columnar cells lining dysplastic glands. In the subjacent mucosa numerous Paneth cells are present. (PAP technique-hematoxylin.)

When the histochemical methods for mucins were applied either as a counterstain or on serial sections to those stained immunohistochemically for lysozyme, a supranuclear positivity for lysozyme (figs 4 and 5) and an apical secretion of a variable amount of neutral mucins (fig 5), sialomucins, and sulphomucins (fig 6) could often be seen lining severely dysplastic tubules in columnar cells.

The simultaneous demonstration of alcian blue and lysozyme reactivity on the same tissue sections also allowed intermediate Paneth-goblet cells to be identified in 11 adenomas, 10 of which were located in the fundus and one in the antrum. Some of these intermediate cells showed a lysozyme positivity in coarse and fine granules in the supranuclear cytoplasm, whereas in the apical cytoplasm there was an 


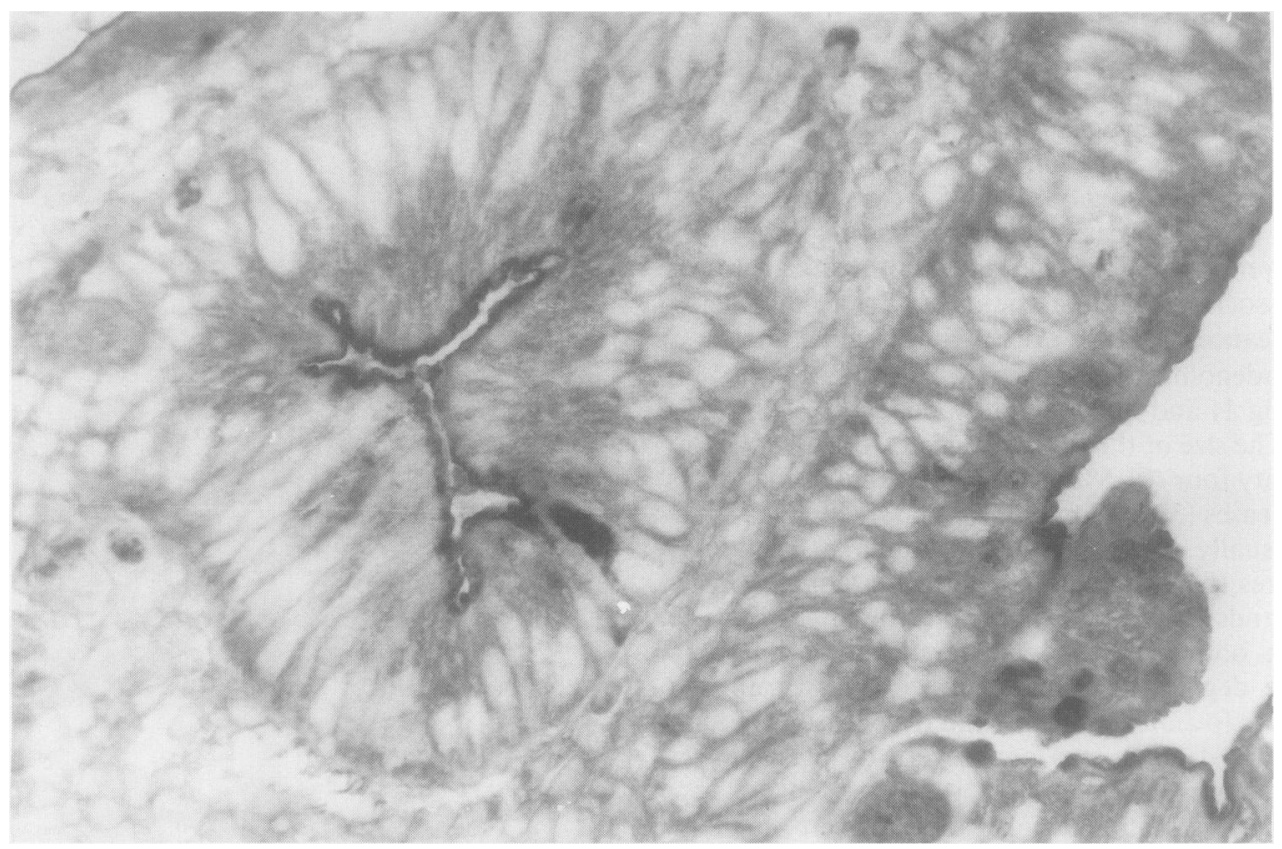

Fig 4 Simultaneous application of the PAP method for lysozyme and staining with PAS showing supranuclear lysozyme immunoreactivity and apical neutral mucins in the cytoplasm of the dysplastic columnar cells.

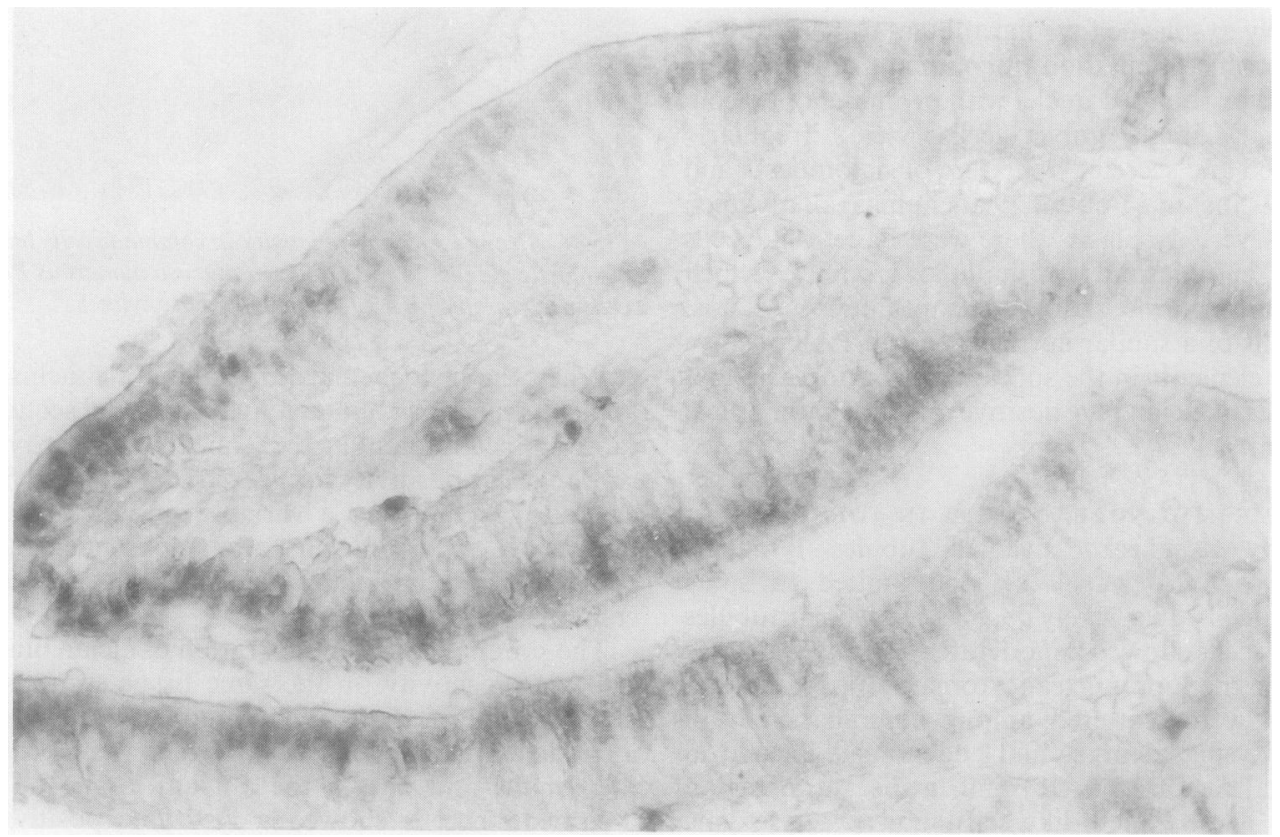

Fig 5 Intense supranuclear lysozyme positivity is evident in dysplastic columnar cells. (PAP technique.) 


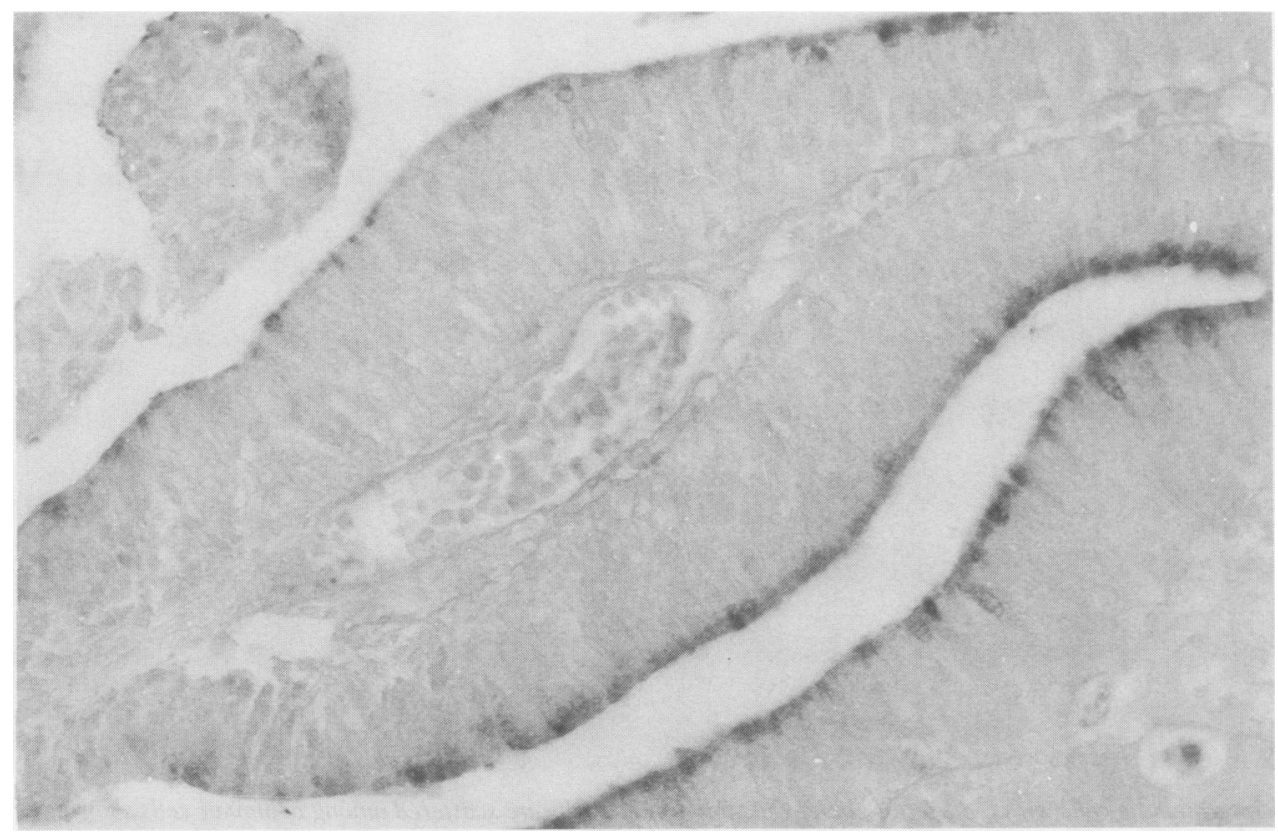

Fig 6 Section adjacent to that in fig 5 shows high iron diamine staining demonstrative of sulphomucins confined to apical cytoplasm of dysplastic columnar cells.

aggregation of alcian blue positive material (fig 7). Lysozyme positive granular elements were interspersed among alcian blue positive mucin droplets in the cytoplasm.

In the lower layer subjacent to the adenoma type IIa, incomplete intestinal metaplasia was commonly observed but some lysozyme positive Paneth cells were also demonstrable in five adenomas in the fundus (fig 3). Lysozyme immunoreactivity was found in numerous epithelial cells of cystically dilated glands.

\section{Discussion}

Most adenomas were located in the antral $(51 \%)$ and fundal regions $(43 \%)$ with a few in the cardia $(5 \%)$. Adenomas were polypoid in $38.5 \%$ and flat or slightly raised in $61.5 \%$. Histologically, they displayed a tubular $(61.5 \%)$ or papillotubular growth pattern (39.5\%).

Paneth-like cells have been observed morphologically ${ }^{13}$ and immunohistochemically ${ }^{14}$ in gastric adenomas. The combination of standard histochemical staining with immunohistochemical techniques allowed more than one differentiated function in a cell to be identified at light microscopic level. Not only were Paneth-like cells shown, but also intermediate cells between small, goblet cells, and Paneth cells in 10 adenomas situated in the fundus and one in the antrum. Fundal mucosa was more likely to be the site of the adenomas with Paneth-like cells and intermediate Paneth-goblet cells than the antral mucosa. This close topographical relation was also found by Ito et al, ${ }^{14}$ who showed that tubular adenomas in the fundus contain numerous Paneth cells as does fundal intestinal metaplasia. This was also confirmed by our finding a small number of Paneth cells in the non-neoplastic mucosa lying just below five adenomas located in the fundal region. Paneth-goblet cells have been described ultrastructurally ${ }^{15}$ or immunohistochemically ${ }^{56}$ in samples of small intestine from normal rats and patients with inflammatory bowel diseases. It has consequently been suggested that both these epithelial cells may have a common precursor. ${ }^{616}$ The presence of Paneth-goblet cell hybrids suggests an abnormal differentiation of these intestinal-type epithelial cells in gastric adenomas.

Our findings of goblet cells, Paneth-like cells, and intermediate Paneth-goblet cells in adenomas further support the intestinal metaplastic nature of the lesion, as suggested by several other authors. ${ }^{13} 14^{17-21}$

In normal human stomach lysozyme may usually be found in neutral mucin-secreting cells of the antral and fundal glands ${ }^{124}$ as well as in mucous neck cells, ${ }^{422}$ which produce small amounts of neutral mucins, sialomucins, and sulphomucins. ${ }^{2324}$ The adenoma columnar cells, particularly in severely dysplastic 


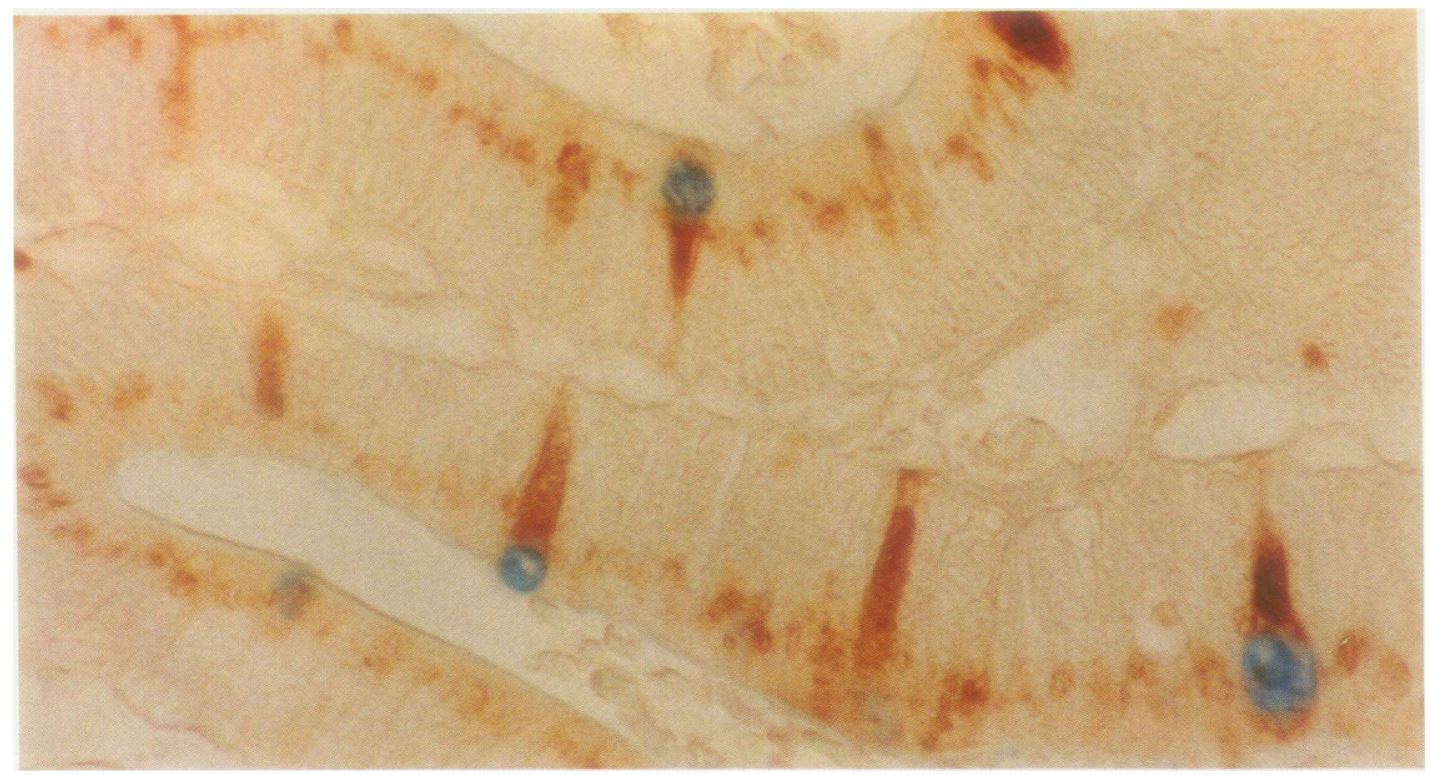

Fig 7 Intermediate cells with features of goblet cells and Paneth cells are scattered among columnar cells showing a supranuclear lysozyme reactivity. Sections have been exposed to the antilysozyme antibody, then to alcian blue. No counterstain was applied.

foveolar tubules, show a clear polarisation of lysozyme reactivity in the supranuclear cytoplasm and small amounts of neutral mucins, sialomucins, and sulphomucins in the apical cytoplasm. Our findings suggest that these abnormally differentiated columnar cells reproduce the partially differentiated mucous neck cells of the normal proliferative zone, retaining or modifying some of their functional characteristics. On the other hand, cell kinetic studies have shown that gastric adenomas arise from the neck stem cells of the mucosa, as in the case with intestinal metaplasia. ${ }^{25}$ Thus lysozyme producing, mucin positive columnar cells, as well as Paneth-goblet cells, may have their origins in the partially differentiated neck cells of the gastric mucosa.

In conclusion, the combination of standard histochemical and immunohistochemical techniques for showing lysozyme reactivity allows abnormally differentiated, intermediate cell populations to be identified in gastric adenomas, a disease in which cellular turnover is greatly increased.

\section{References}

1 Mason DY, Taylor CR. The distribution of muramidase (lysozyme) in human tissues. J Clin Pathol 1975;28:124-32.

2 Klockars M, Reitamo S. Tissue distribution of lysozyme in man. J Histochem Cytochem 1975;23:923-40.

3 Yamashita $\mathrm{K}$, Iwamoto $\mathrm{T}$, Iijima $\mathrm{S}$. Immunohistochemical observation of lysozyme in macrophages and giant cells in human granulomas. Acta Pathol Jpn 1978;28:689-95.

4 Reitamo S, Reitamo JJ, Sipponen P, Klockars M. The distribution of lysozyme in human gastric mucosa in inflammatory and neoplastic disorders. Acta Pathol Microbiol Scand (Sect A) 1979;87:451-6.

5 Montero C, Erlandsen SL. Immunocytochemical and histochemical studies on intestinal epithelial cells producing both lysozyme and mucosubstances. Anat Rec 1978;190:127-42.

6 Lopez-Lewellyn J, Erlandsen SL. Cytodifferentiation of the rat Paneth cell: an immunocytochemical investigation in suckling and weanling animals. Am J Anat 1980;158:285-97.

7 Tahara E, Ito H, Shimamoto F, Iwamoto T, Nakagami K, Niimoto H. Lysozyme in human gastric carcinoma: a retrospective immunohistochemical study. Histopathology 1982;6:409-21.

8 Ohtani H, Sasano N. Ultrastructural immunolocalization of lysozyme in Paneth-like cells in undifferentiated (gastric)-type carcinoma of the stomach. Acta Pathol Jpn 1988;38:861-72.

9 Sternberger LA. Immunocytochemistry. 2nd ed. New York: J Wiley, 1979.

10 Graham RC, Karnovsky MJ. The early stages of absorption of injected horseradish peroxidase in the proximal tubules of mouse kidney: ultrastructural cytochemistry by a new technique. J Histochem Cytochem 1966;14:291-302.

11 Jass JR, Filipe MI. The mucin profiles of normal gastric mucosa, intestinal metaplasia and its variants and gastric carcinoma. Histochem J 1981;13:931-9.

12 World Health Organization. Histological typing of gastric and oesophagus tumours. In International Histological Classification of Tumors No 18. Geneva: WHO, 1977.

13 Nagayo T. Histological diagnosis of biopsied gastric mucosae with special reference to that of borderline lesions. Gann Monograph Cancer Res 1971;11:245-56.

14 Ito $H$, Hata J, Yokozaki H, Nakatani H, Ode N, Tahara E. Tubular adenoma of the human stomach. An immunohistochemical analysis of gut hormones, serotonin, carninoembryonic antigen, secretory component, and lysozyme. Cancer 1986;58:2264-72.

15 Subbuswamy SG. Paneth cells and goblet cells. J Pathol 
1973;111:181-91.

16 Cheng H, Leblond CP. Origin, differentiation and renewal of the four main epithelial cell types in the mouse small intestine. V. Unitarian theory of the origin of the four epithelial cell types. Am J Anat 1974;141:537-62.

17 Cuello C, Correa P, Zarama G, Lopez J, Murray J, Gordillo G. Histopathology of gastric dysplasia. Am J Surg Pathol 1979;3:491-500.

18 Morson BC, Sobin LH, Grundmann E, Johansen A, Nagayo T, Serck-Hanssen A. Precancerous conditions and epithelial dysplasia of the stomach. J Clin Pathol 1980;33:231-40.

19 Jass JR, Filipe MI. Sulphomucins and precancerous lesions of the human stomach. Histopathology 1980;4:271-9.

20 Grundmann E. Classification and clinical consequences of precancerous lesions in the digestive and respiratory tracts. Acta Pathol Jpn 1983;33:195-217.

21 Hirota T, Hokada T, Itabashi M, et al. Significance of intestinal metaplasia as a precancerous condition of the stomach. In:
Ming SC, ed. Precursors of gastric cancer. New York: Praeger, 1984:179-93.

22 Isaacson P. Immunoperoxidase study of the secretory immunoglobulin system and lysozyme in normal and diseased gastric mucosa. Gut 1982;23:578-88.

23 Filipe MI. Mucins in the human gastrointestinal epithelium: A review. Invest Cell Pathol 1979;3:195-216.

$24 \mathrm{Gad} \mathrm{A}$. Intestinal metaplasia and gastric carcinoma. In Ming SC, ed. Precursors of gastric cancer. New York: Praeger, 1984: 195-206.

25 Hattori T. Histological and autoradiographic study on development of group III lesion (Dysplasia grade III) in the stomach. Path Res Pract 1985;180:36-44.

Requests for reprints to: Dr Caruso Rosario Alberto, Dipartimento di Patologia Umana, Policlinico Universitario pad D, 98100 Messina, Italy. 